\title{
Potentials of Trifoliate Yam (Dioscorea dumetorum) in Noodles Production Akinoso $\mathbf{R}^{1}$, Olatoye $\mathrm{KK}^{\mathbf{2}^{*}}$ and Ogunyele $\mathrm{OO}^{1}$ \\ ${ }^{1}$ Department of Food Technology, Faculty of Technology, University of Ibadan, Nigeria \\ ${ }^{2}$ Department of Food, Agriculture and Bio-engineering, College of Engineering and Technology, Kwara State University, Kwara State, Nigeria
}

\begin{abstract}
Trifoliate yam (Dioscorea dumetorum) is a high yielding but under exploited yam species. Potential of its flour in noodle production was investigated in this study. Trifoliate yam flour was produced and substituted for wheat flour at $20-70 \%$ levels. Noodles were produced from the composite flour and evaluated for their proximate composition, functional properties, colour and cooking properties, using standard methods. Sensory attributes of the noodle were also determined using panelists. Data were analyzed using ANOVA at $(p<0.05)$. The results showed that incorporation of trifoliate yam flour into wheat flour increased the moisture, crude fibre, ash and fat content of dried noodles. The moisture content ranges from $7.16-12.93 \%$, crude fiber $(0.72$ $1.30 \%)$, Ash (1.20 - 2.88\%), fat (18.26 - 28.54\%), protein (5.88 - 7.79\%) and carbohydrate $(51.18-62.77 \%)$. The water and oil absorption capacities of the noodles increased from $1.60 \mathrm{~g}$ to $2.03 \mathrm{~g}$ and $0.72 \mathrm{~g}$ to $1.21 \mathrm{~g}$ respectively, with increase in levels of trifoliate yam flour. Significant differences $(p<0.05)$ exist between the colour of raw sheet noodles and the cooked noodles. The optimum cooking time and cooking loss were in the ranges $(5.43 \mathrm{~min}$ to $7.06 \mathrm{~min}$ ) and $(9.31-15.09 \%)$ respectively. Sensory evaluation showed that the acceptability of uncooked and cooked dried noodles were at the moderate level. The substitution of different levels of trifoliate yam flour did not give significant $(p<0.05)$ influence on sensory attributes except for the taste and color of dried noodles. Trifoliate yam has a good utilization potential in noodle production and could be used as substitute to wheat in human nutrition and in the food industries since they compare favorably in their nutritional compositions.
\end{abstract}

Keywords: Trifoliate yam; Noodles production; Sensory evaluation; Chemical composition

\section{Introduction}

Yam (Dioscorea sp.) is one of the most important staple food crops in West Africa especially Nigeria [1]. Yams are annual or perennial tuberbearing and climbing plant with over 600 species, in which only few are cultivated for food and medicine [2]. Some yam varieties are widely used for food while others are underutilized. Trifoliate yam (Dioscorea dumetorum) is an under-exploited but high yielding yam species [3]. It has also been reported to be nutritionally superior to the commonly consumed yams with high protein and minerals [4]. It has starch grains that are smaller, more digestible than those of other yam species. Trifoliate yam tuber however, contains some anti-nutrient contents as a result of which slight bitterness may be experienced [5]. In addition, this yam species hardens few days after harvest leading to reduction in moisture and starch content and increase in sugar as well as structural polysaccharides [6]. Intensive processing like prolonged soaking and blanching are expected to eliminate these defects. Transforming its tubers into edible flour constitutes a means of conferring a long-term value onto it. Today, people's preference towards convenience food products has cumulated in many adverse consequences including hike in price and increase in the demand for importation of wheat. Noodles, which are convenient pasta products, are basically prepared from unleavened dough of durum wheat semolina and are only second to bread in popularity as staple food, globally [7]. They are nutritious and delicious, containing complex carbohydrates, which can provide long lasting energy and help to feel full for long periods. They are consumed in all five continents, with increased awareness of its nutritional benefits [8]. Noodles preparation by supplementations of wheat flour with other food materials have been documented; cassava [9], matured green banana and oat beta glucan [10], green banana [11], unripe plantain [12]. Better alternative usefulness of these materials is many; therefore involvement of underutilized materials like trifoliate yam could be more economically viable. Incorporation of its flour into wheat flour will reduce pressure on the latter while concomitantly promoting the industrial utilization of the former in pastry. Thus, this research work aimed at reducing food insecurity bane by promoting the utilization of trifoliate yam through substituting its flour in the noodle formulation.

\section{Materials and Methods}

\section{Materials}

Trifoliate yam (Dioscorea dumentorum), clean and free from bruises, was obtained from Malete, Ilorin, Kwara State. Sodium carbonate, potassium carbonate, gelatin, Iodized salt, ascorbic acid, Sodium phosphate (analytical grades), Eggs and edible oil and all the equipment used were supplied by the Department of Food Technology, University of Ibadan, Oyo state, Nigeria.

\section{Methods}

Production of trifoliate yam flour (TYF): Trifoliate yam tubers were processed into flour according to procedure of Abiodun et al. [13] as shown in Figure 1.

Preparation of noodles: Noodles were prepared following the procedures of Nagao [14] as shown in Figure 2. Noodles produced from six different blends of trifoliate yam flour and wheat flour with their codes was shown in Table 1. Basic ingredients and combinations were presented in Table 2.

\section{Functional properties}

Determination of bulk density: Bulk density and oil absorption capacity were determined by adopting the method of Udensi and Okaka [15]. $3 \mathrm{~g}$ of each sample was weighed into $10 \mathrm{ml}$ graduated cylinders and tapping ten times against the palm of hand. The volume

*Corresponding author: Olatoye KK, Department of Food, Agriculture and Bioengineering, College of Engineering and Technology, Kwara State University, Malete, P.M.B 1530, Ilorin, Kwara State, Nigeria, Tel: + 234-8023885622 ; E-mail: luckykaykay@yahoo.com

Received June 16, 2016; Accepted July 05, 2016; Published July 12, 2016

Citation: Akinoso R, Olatoye KK, Ogunyele OO (2016) Potentials of Trifoliate Yam (Dioscorea dumetorum) in Noodles Production. J Food Process Technol 7: 609. doi:10.4172/2157-7110.1000609

Copyright: (C) 2016 Akinoso R, et al. This is an open-access article distributed under the terms of the Creative Commons Attribution License, which permits unrestricted use, distribution, and reproduction in any medium, provided the original author and source are credited. 


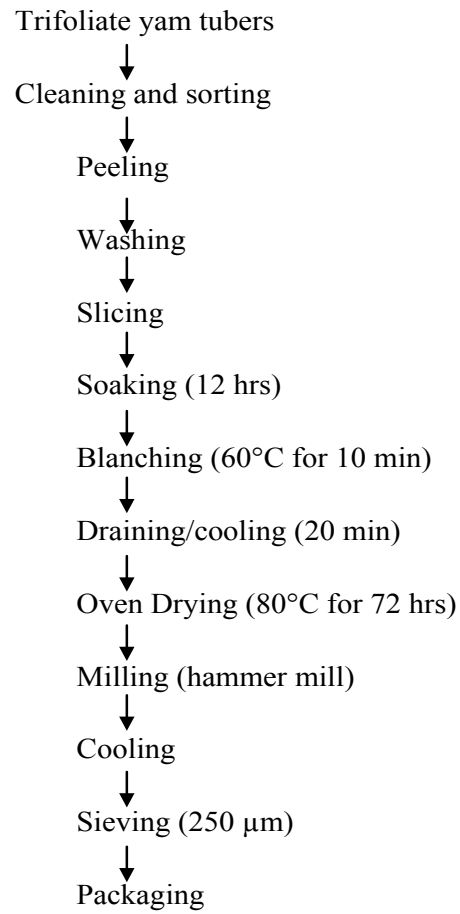

Figure 1: Production of trifoliate yam flour [13].

\begin{tabular}{|c|c|}
\hline Code & TYF: WF \\
\hline $\mathrm{Y}_{0} \mathrm{~W}_{100}$ & $00: 100$ \\
\hline $\mathrm{Y}_{20} \mathrm{~W}_{80}$ & $20: 80$ \\
\hline $\mathrm{Y}_{30} \mathrm{~W}_{70}$ & $30: 70$ \\
\hline $\mathrm{Y}_{50} \mathrm{~W}_{50}$ & $50: 50$ \\
\hline $\mathrm{Y}_{70} \mathrm{~W}_{30}$ & $70: 30$ \\
\hline $\mathrm{Y}_{100} \mathrm{~W}_{0}$ & $100: 00$ \\
\hline
\end{tabular}

Table 1: Sample codes and blend ratios of trifoliate yam-wheat noodles.

Ingredients Mixing

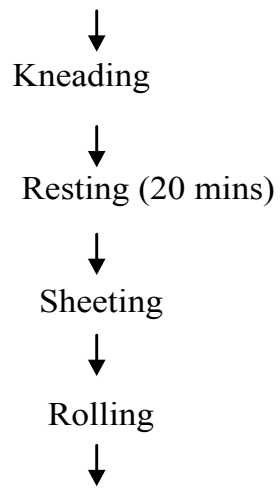

Cutting in sizes

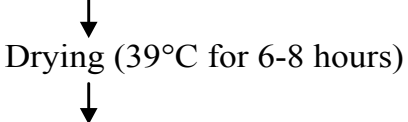

Dried Noodles

Figure 2: Production of trifoliate yam flour into noodles [14]. of sample was recorded after tapping was recorded and bulk density was expressed as $\mathrm{g} / \mathrm{ml}$.

Determination of water absorption capacity: Water binding capacity of noodles was determined according to the method of AACC [16]. Aqueous suspension of noodles was made by dissolving $2 \mathrm{~g}$ (dry weight) of noodle in $40 \mathrm{ml}$ of distilled water. The suspension was agitated for 1 hour on a Griffin flask shaker and centrifuged at 2200 rpm for 10 minutes. The free water (supernatant) was decanted from the wet sample, drained for 10 minutes and the wet sample was then weighed. The water absorption capacity was calculated by difference using equation 1 .

$$
\% \text { Water absorption capacity }=\frac{\text { Weight of bound } \text { water }}{\text { Weight of } \text { sample }} \times 100
$$

Oil absorption capacity: The method of Kinsella JE and Melachouris [17] was used. One gram meal that was mixed with $10 \mathrm{ml}$ refined vegetable oil (Gino) in a weighted $25 \mathrm{ml}$ centrifuge tube was thoroughly stirred for $2 \mathrm{~min}$ and then centrifuge at $4000 \mathrm{rpm}$ for 20 min. the supernatant was discarded, the adhering free oil was removed and the tube and content was re-weighed. Oil absorption capacity as expressed as weight of oil bound by $100 \mathrm{~g}$ meal.

Determination of solubility index and swelling capacity: Solubility and Swelling power determinations were carried out based on a modification of the method of Iwuoha [18]. One gram of noodle was dissolved with distilled water to a total volume of $40 \mathrm{ml}$ using a weighed $50 \mathrm{ml}$ graduated centrifuge tube. The suspension was stirred just sufficiently and uniformly avoiding excessive speed since it might cause fragmentation of the starch granules. The slurry in the tube was heated at $85^{\circ} \mathrm{C}$ in a thermostatically regulated temperature water bath for 30 minutes with constant gentle stirring. The tube was then removed, wiped dry on the outside and cooled to room temperature. It was then centrifuged at $2200 \mathrm{rpm}$ for 15 minutes. The supernatant was decanted into a pre-weighed moisture can. The solubility was determined by evaporating the supernatant in thermostatically controlled drying oven at $105^{\circ} \mathrm{C}$ and weighing the residue (Equation 2). The sediment paste was weighed and swelling capacity was calculated as the weight of sediment paste per gram of noodle used (Equation 3).

$$
\begin{aligned}
& \% \text { Solubility }=\frac{\text { Weight of soluble }}{\text { Weight of sample }} \times 100 \\
& \text { Swelling capacity }=\frac{\text { Weight of sediment }}{\text { Sample weight }- \text { Weight ofsoluble }}
\end{aligned}
$$

Cooking time: Optimal cooking time was evaluated by observing the time of disappearance of the core of the noodle strand during cooking (every $30 \mathrm{~s}$ ) by squeezing the noodles between two transparent glass slides. About $10 \mathrm{~g}$ of noodles was cooked in $300 \mathrm{ml}$ of distilled water in a covered $500 \mathrm{ml}$ beaker. Cooking time was determined by the removal of a strand of noodle every 30 seconds and pressing the noodle between two pieces of watch glasses. Optimum cooking was achieved when the center of the noodles became transparent. Cooking was stopped by rinsing with distilled water.

Cooking loss: The cooking loss was determined by measuring the amount of solid substance lost to cooking water. A $10 \mathrm{~g}$ sample of noodles was placed into $300 \mathrm{ml}$ of boiling distilled water in a $500 \mathrm{ml}$ beaker. Cooking water was collected in an aluminum vessel which was placed in an air oven at $105^{\circ} \mathrm{C}$ and evaporated to dryness. The residue was weighed and reported as a percentage of the starting material. For each optimal cooking time and cooking loss value, five determinations were performed to obtain the mean values (Equation 4) 


$$
\text { Cooking loss }(\%)=\frac{\text { Dried residue in cooking water }}{\text { Noodle weight before cooking }} \times 100
$$

Water uptake: The water uptake was determined by the ratio of the weight of cooked noodle to the weight of noodle before cooking (Equation 5)

Water uptake $(\%)=\frac{\text { Weight of cooked noodle }}{\text { Weight of noodle before cooking }}$

Determination of colour: The color of the dried noodle sheets and the optimally cooked noodle samples were measured with a Chroma-meter (Minolta, Tokyo, Japan) equipped with a D65 illuminant using the CIE $\mathrm{L}^{*} \mathrm{a}^{*} \mathrm{~b}^{*}$ system. The $\mathrm{L}^{*}, \mathrm{a}^{*}$ and $\mathrm{b}^{*}$ readings were obtained directly from the instrument and provided measures of lightness, redness and yellowness, respectively. All measurements were performed in triplicate and mean value recorded.

Sensory evaluation: Cooked samples were evaluated for appearance, flavor, taste, texture, colour and overall acceptability by 30 untrained panelists using nine-point hedonic scales, where 9 and 1 were extremely like dislike respectively.

Statistical analysis: Means of triplicate data were recorded. There were subjected to one-way analysis of variance (ANOVA), means were separated using Duncan multiple range test at 0.05 significance level using SPSS software.

\section{Results and Discussions}

\section{Proximate compositions}

Substitution of TYF for Wheat flour significantly $(\mathrm{p}<0.05)$ influenced the proximate composition of noodles, (Table 3 ). The moisture content ranged between $(9.09-12.16 \%)$ for 20 - 70\% levels. Noodle sample $\mathrm{Y}_{100} \mathrm{~W}_{0}$ had highest mineral content of $(12.93 \%) \mathrm{db}$, while (control) $\mathrm{Y}_{0} \mathrm{~W}_{100}$ had the least $(8.50 \%)$. The higher moisture content found in $\mathrm{Y}_{100} \mathrm{~W}_{0}$ might be due to water holding capacity of fibers and polysaccharides in trifoliate yam flour during the dough formation. The results of moisture content were close to a safe moisture level $(\leq 10 \%)$ for long term storage of flour. The capabilities of yam flours to hold more water are related to the higher fiber content compared with other flours [19]. Crude Protein ranged (5.88 - 7.79\%) were significantly $(\mathrm{p}<0.05)$ reduced with substitution levels of TYF. This result was closer to $(7-8 \%)$ minimum recommended for prevention of PEM (protein-energy malnutrition) by UNO/WHO [20]. Yap and Chen [21] similarly reported a decreased in protein content in the wet noodles when substitution proportion were raised. Crude Ash content ranged $1.20-2.88 \%$ and decreased when the trifoliate yam flour amount in some noodles increased and also increased in some noodles. Noodle prepared from $\mathrm{Y}_{30} \mathrm{~W}_{70}$ has the highest ash content of $2.88 \%$ and was reduced to $2.57 \%$ at $\mathrm{Y}_{70} \mathrm{~W}_{30}$. The ash content depends on the quality of the flour and thus corresponds to the higher mineral content, especially potassium. $\mathrm{Y}_{100} \mathrm{~W}_{0}$ noodle has the lowest ash content of $1.20 \%$. These values were still closer to $3 \%$ for maximum ash content in first quality dried noodle and higher than $0.012-0.030 \%$ ash content reported by Chang and $\mathrm{Wu}$ [22] in seaweeds powders substitution. However, $\mathrm{Y}_{20} \mathrm{~W}_{80}$ and $\mathrm{Y}_{70} \mathrm{~W}_{30}$ noodles showed no significant different ( $\mathrm{p} \leq 0.05$ ) with $\mathrm{Y}_{0} \mathrm{~W}_{100}$ noodle. Ash content is a reflection of mineral status, though contamination can indicate a high concentration in a sample. Crude Fat content was at the range between $18.43-28.54 \%$, and significantly higher $(\mathrm{p}<0.05)$ than $3.3 \%$ fat content recommended by the Ministry of Health on the wet noodle [23]. This might be due to higher oil absorption capacity of TYF than the WF in the control formulation. The results were in disagreement with Wang et al. [24] whose fat content of noodles decreases as the substitution level of green banana flour increases. This result was however similar to Senthil et al [25] and lower than 13.37 - 21.50\%, reported by Gabriel and Faith [26] in similar studies. The lipid components will contribute to the texture, flavor and aroma of foods, thereby prolonging satiety and facilitate the absorption of lipid-soluble vitamins [27]. Crude fibre contents of noodles incorporated with trifoliate yam flours were between 0.72 and $1.30 \% . \mathrm{Y}_{30} \mathrm{~W}_{70}$ noodle had higher fibre content than the $\mathrm{Y}_{0} \mathrm{~W}_{100}$ noodles i.e., control (0.99\%). Fibre is important for the removal of waste from the body thereby preventing constipation and many health disorders [28]. Carbohydrate content, varies between (51.18 - 62.77\%) and decreases with increased trifoliate yam flour addition. There were significant differences $(p<0.05)$ between dried noodle control and noodle made from trifoliate yam flour substitution. Similar result was documented by Wirjatmadi et al. [29]. The Ministry of Health required not less than $14 \%$ of carbohydrate content on wet noodles [30].

\section{Functional properties of trifoliate-wheat noodles}

Functional properties are characteristics of a substance that affect its behavior and that of products to which it is added during food processing [31]. Results of functional Properties of Trifoliate-Wheat Noodles were presented in (Table 4). Control sample $\left(\mathrm{Y}_{0} \mathrm{~W}_{100}\right)$ had the highest degree of bulkiness (0.72) and bulkiness ranged between (0.610.72). Bulk density was significantly decreased with addition of TYF to Wheat flour. Bulk density is a measure of heaviness of a flour sample. Incorporated of TYF significantly increased $(\mathrm{p}<0.05)$ the WAC with increase in substitution level and ranged between ( $1.60 \mathrm{~g}$ to $2.03 \mathrm{~g}$ ), with $\mathrm{Y}_{0} \mathrm{~W}_{100}$ the least and $\mathrm{Y}_{100} \mathrm{~W}_{0}$ the highest. High water binding capacities

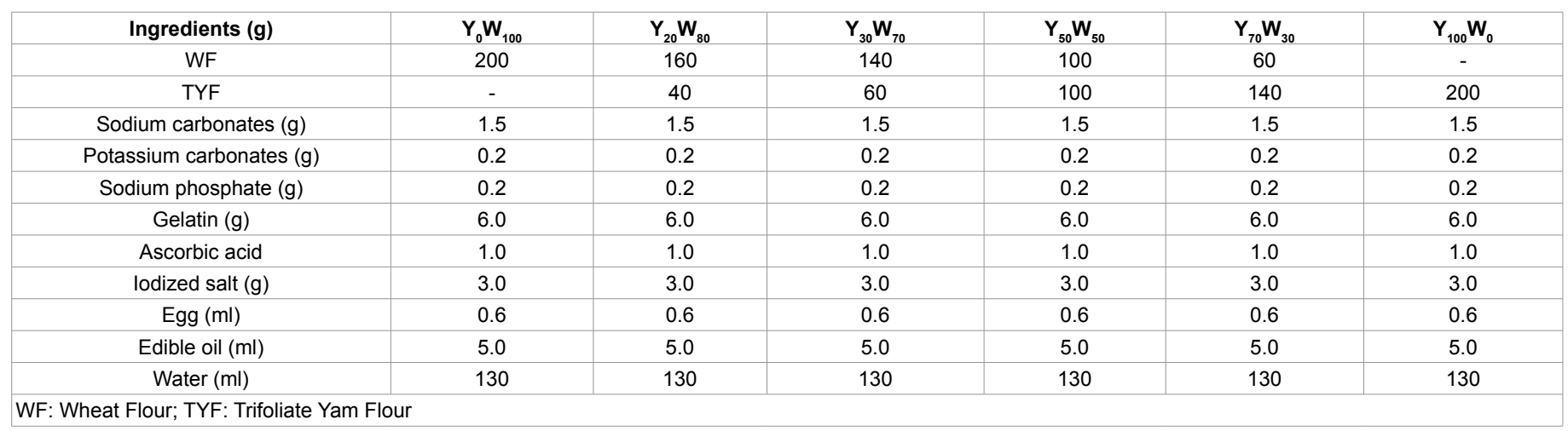

Table 2: Recipe for trifoliate yam-wheat noodles. 
are desirable as they increase the unit yield of products. It stabilizes starches against effects such as seneresis, which sometimes occurs during retorting and freezing [32-34]. Similar trend was observed on OAC, with $\mathrm{Y}_{100} \mathrm{~W}_{0}$ being the highest $(1.21 \mathrm{~g})$ and control noodle, the least $(0.72 \mathrm{~g})$. This result disagrees with Siddaraju et al. [35]. Oil absorption is an important property in food formulations because fats improve the flavour and mouth feel of foods [17]. Water binding capacity is also an important functional characteristic in the development of ready-to-eat foods since high water absorption capacity may assure product cohesiveness [36]. Swelling capacity of noodles reduces with substitution levels and ranged between $(3.33 \mathrm{~g}$ to $5.11 \mathrm{~g})$. $\mathrm{Y}_{100} \mathrm{~W}_{0}$ had the least value $(3.33 \mathrm{~g})$ and $\mathrm{Y}_{0} \mathrm{~W}_{100}$ the highest $(5.11 \mathrm{~g})$. Variation in the Swelling power can be traced to differences in their associative forces. This may explain its hard and waxy texture as revealed from sensory evaluation. Solubility indices of noodles varied significantly $(\mathrm{p}<0.05)$ and ranged (8.01-11.07\%). There was no significant difference between the control sample and noodles from TYF/WF blends up to $30 \%$ substitution level. Riley et al. [30] reported that solubility increased with decreasing amylose content. The observation for the noodles is similar with the result obtained from of Soni et al. [37] who associated high solubility with high amylose content. The difference could be attributed to differences in granule sizes and their arrangement within their cells.

\section{Colour of trifoliate yam-wheat noodles}

Colour characteristics of raw sheet and optimally cooked noodles prepared from different levels of trifoliate yam flour substituted with wheat flour are shown in Table 5. The results indicated that, as the amount of trifoliate yam flour increased, the appearance of the raw sheet and the cooked noodles grew darker. The darkness is likely a product of the Maillard reaction between reducing sugars and proteins [38]. The redness $\left(a^{*}\right)$ also increased, while yellowness $\left(b^{*}\right)$ decreased with increased addition of TYF. These changes in colour can also be attributed to the higher amount of oxidized phenol compounds in TYF noodles. Similar results have been reported for crackers incorporated green banana flour [24] and yeast leavened banana-bread [38]. Color is a key quality trait [39] because of the visual impact at the point of sale. It provides some indication of the quality of the starting materials and, in some cases, the age of the product.

\section{Cooking properties of trifoliate yam-wheat noodles}

Inclusion of TYF in noodles production significantly $(\mathrm{p}<0.05)$ influenced the cooking properties. Cooking times of all noodle samples increased with increase in TYF and ranged from $5.43 \mathrm{~min}$ to $7.06 \mathrm{~min}$, with $\mathrm{Y}_{0} \mathrm{~W}_{100}$ and $\mathrm{Y}_{100} \mathrm{~W}_{0}$ being the least and highest respectively (Table 6). Similar trend was observed with cooking loss. The cooking loss is the amount of dry matter in the cooking water of optimally cooked noodles. An increase in the cooking loss with noodles substitute with TYF may have been due to weakening of the protein network by the presence of trifoliate yam flour. This may allow more solids to be leached out from the noodles into the cooking water [40]. These results are in the agreement with Ovando- Martinez et al. [41] who reported that partial or complete substitution of durum wheat semolina with fibre material can result in negative changes to pasta quality, including increased cooking loss. Water uptake and cooking weight also increases as the level of TFY in the noodle increases. $Y_{30} W_{70}$ has the lowest water uptake and cooking weight and is not significantly $(\mathrm{p}<0.05)$ different with that of control. The water uptake and cooking weight were observed to increase as TYF addition increases, with $100 \%$ having the highest in

\begin{tabular}{|c|c|c|c|c|c|c|}
\hline Noodles Sample & Moisture (\%) & Crude Ash (\%) & Crude Fat (\%) & Crude fibre (\%) & Crude protein (\%) & Carbohydrate (\%) \\
\hline $\mathrm{Y}_{0} \mathrm{~W}_{100}$ & $8.50 \pm 0.14^{\mathrm{a}}$ & $2.50 \pm 0.03^{\mathrm{a}}$ & $18.43 \pm 0.15^{\mathrm{f}}$ & $0.99 \pm 0.00^{\mathrm{a}}$ & $7.79 \pm 0.02^{\mathrm{c}}$ & $62.77 \pm 0.34^{\mathrm{a}}$ \\
\hline $\mathrm{Y}_{20} \mathrm{~W}_{80}$ & $9.09 \pm 0.13^{\mathrm{b}}$ & $2.41 \pm 0.07^{\mathrm{ab}}$ & $20.15 \pm 0.12^{\mathrm{e}}$ & $0.97 \pm 0.01^{\mathrm{ab}}$ & $7.21 \pm 0.01^{\mathrm{b}}$ & $62.11 \pm 0.06^{\mathrm{c}}$ \\
\hline $\mathrm{Y}_{30} \mathrm{~W}_{70}$ & $9.77 \pm 0.01^{\mathrm{c}}$ & $2.88 \pm 0.00^{\mathrm{c}}$ & $23.73 \pm 0.04^{\mathrm{a}}$ & $1.30 \pm 0.01^{\mathrm{d}}$ & $6.94 \pm 0.05^{\mathrm{e}}$ & $56.68 \pm 0.10^{\mathrm{b}}$ \\
\hline $\mathrm{Y}_{50} \mathrm{~W}_{50}$ & $11.69 \pm 0.07^{\mathrm{d}}$ & $2.29 \pm 0.08^{\mathrm{b}}$ & $28.54 \pm 0.01^{\mathrm{b}}$ & $0.72 \pm 0.01^{\mathrm{c}}$ & $6.30 \pm 0.01^{\mathrm{a}}$ & $51.18 \pm 0.14^{\mathrm{d}}$ \\
\hline $\mathrm{Y}_{70} \mathrm{~W}_{30}$ & $12.16 \pm 0.02^{\mathrm{e}}$ & $2.57 \pm 0.07^{\mathrm{a}}$ & $21.89 \pm 0.00^{\mathrm{c}}$ & $0.76 \pm 0.03^{\mathrm{c}}$ & $6.72 \pm 0.01^{\mathrm{f}}$ & $61.67 \pm 0.09^{\mathrm{c}}$ \\
\hline $\mathrm{Y}_{100} \mathrm{~W}_{0}$ & $12.93 \pm 0.01^{\mathrm{f}}$ & $1.20 \pm 0.00$ & $26.26 \pm 0.04^{\mathrm{d}}$ & $0.93 \pm 0.00^{\mathrm{b}}$ & $5.88 \pm 0.02^{\mathrm{d}}$ & $53.23 \pm 0.07^{\mathrm{e}}$ \\
\hline
\end{tabular}

Significant differences is indicated by different letters within the same rom. $(p \leq 0.05)$

Table 3: Proximate composition of trifoliate-wheat noodles.

\begin{tabular}{|c|c|c|c|c|c|}
\hline Noodles Sample & Bulk Density g/ml & WAC (g) & OAC (g) & Swelling Capacity(g) & Solubility Index (\%) \\
\hline $\mathrm{Y}_{0} \mathrm{~W}_{100}$ & $0.72 \pm 0.00^{\mathrm{a}}$ & $1.60 \pm 0.01^{b}$ & $0.72 \pm 0.01^{\mathrm{e}}$ & $5.11 \pm 0.10^{\mathrm{a}}$ & $9.94 \pm 0.05^{a}$ \\
\hline $\mathrm{Y}_{20} \mathrm{~W}_{80}$ & $0.67 \pm 0.00^{b}$ & $1.91 \pm 0.01^{\mathrm{a}}$ & $0.75 \pm 0.00^{d}$ & $4.26 \pm 0.01^{c}$ & $9.96 \pm 0.01^{\mathrm{a}}$ \\
\hline $\mathrm{Y}_{30} \mathrm{~W}_{70}$ & $0.63 \pm 0.00^{d}$ & $1.61 \pm 0.01^{\mathrm{bc}}$ & $0.87 \pm 0.00^{c}$ & $4.95 \pm 0.02^{b}$ & $9.92 \pm 0.01^{\mathrm{a}}$ \\
\hline $\mathrm{Y}_{50} \mathrm{~W}_{50}$ & $0.61 \pm 0.00^{e}$ & $1.71 \pm 0.00^{\mathrm{e}}$ & $0.99 \pm 0.00^{\mathrm{a}}$ & $3.54 \pm 0.01^{d}$ & $8.01 \pm 0.02^{b}$ \\
\hline $\mathrm{Y}_{70} \mathrm{~W}_{30}$ & $0.66 \pm 0.01^{\mathrm{bc}}$ & $1.63 \pm 0.00^{c}$ & $0.93 \pm 0.01^{b}$ & $3.50 \pm 0.01^{\text {de }}$ & $8.13 \pm 0.02^{c}$ \\
\hline $\mathrm{Y}_{100} \mathrm{~W}_{0}$ & $0.63 \pm 0.00^{d}$ & $2.03 \pm 0.01^{\mathrm{d}}$ & $1.21 \pm 0.01^{f}$ & $3.33 \pm 0.03^{e}$ & $11.07 \pm 0.02^{d}$ \\
\hline
\end{tabular}

Significant differences is indicated by different letters within the same rom. $(p \leq 0.05)$

Table 4: Functional properties of trifoliate-wheat noodles.

\begin{tabular}{|c|c|c|c|c|c|c|}
\hline $\begin{array}{l}\text { Noodles } \\
\text { Sample }\end{array}$ & L* Raw Sheet Noodle & $a^{*}$ Raw Sheet Noodle & b* Raw Sheet Noodle & $\begin{array}{c}\text { L* Optimally Cooked } \\
\text { Noodle }\end{array}$ & $\begin{array}{c}\text { a* Optimally Cooked } \\
\text { Noodle }\end{array}$ & $\begin{array}{c}\text { b* Optimally Cooked } \\
\text { Noodle }\end{array}$ \\
\hline$Y_{0} W_{100}$ & $84.53 \pm 0.01^{f}$ & $-1.44 \pm 0.01^{c}$ & $19.77 \pm 0.01^{a}$ & $73.46 \pm 0.01^{\dagger}$ & $-2.11 \pm 0.01^{a}$ & $20.07 \pm 0.21^{d}$ \\
\hline$Y_{20} W_{80}$ & $69.66 \pm 0.01^{\mathrm{e}}$ & $2.24 \pm 0.01^{\mathrm{a}}$ & $21.72 \pm 0.03^{b}$ & $53.03 \pm 0.01^{\mathrm{e}}$ & $3.86 \pm 0.01^{b}$ & $15.53 \pm 0.01^{c}$ \\
\hline $\mathrm{Y}_{30} \mathrm{~W}_{70}$ & $72.19 \pm 0.01^{d}$ & $2.26 \pm 0.00^{\mathrm{ab}}$ & $19.42 \pm 0.10^{c}$ & $48.04 \pm 0.01^{d}$ & $3.24 \pm 0.01^{c}$ & $12.59 \pm 0.01^{\mathrm{a}}$ \\
\hline $\mathrm{Y}_{50} \mathrm{~W}_{50}$ & $68.03 \pm 0.01^{c}$ & $2.28 \pm 0.01^{\mathrm{b}}$ & $18.53 \pm 0.01^{d}$ & $45.68 \pm 0.01^{c}$ & $4.77 \pm 0.01^{\mathrm{d}}$ & $14.63 \pm 0.01^{\mathrm{b}}$ \\
\hline $\mathrm{Y}_{70} \mathrm{~W}_{30}$ & $71.95 \pm 0.07^{\mathrm{b}}$ & $1.32 \pm 0.01^{\mathrm{d}}$ & $18.31 \pm 0.01^{\mathrm{e}}$ & $47.21 \pm 0.01^{\mathrm{b}}$ & $3.88 \pm 0.01^{b}$ & $12.78 \pm 0.01^{\mathrm{a}}$ \\
\hline $\mathrm{Y}_{100} \mathrm{~W}_{0}$ & $66.82 \pm 0.08^{a}$ & $3.02 \pm 0.01^{\mathrm{e}}$ & $18.83 \pm 0.03^{f}$ & $45.26 \pm 0.01^{a}$ & $4.86 \pm 0.01^{e}$ & $14.55 \pm 0.01^{\mathrm{b}}$ \\
\hline
\end{tabular}

Significant differences is indicated by different letters within the same rom. $(p \leq 0.05)$ 
Citation: Akinoso R, Olatoye KK, Ogunyele OO (2016) Potentials of Trifoliate Yam (Dioscorea dumetorum) in Noodles Production. J Food Process Technol 7: 609. doi:10.4172/2157-7110.1000609

Page 5 of 6

\begin{tabular}{|c|c|c|c|c|}
\hline $\begin{array}{c}\text { Noodles } \\
\text { Sample }\end{array}$ & $\begin{array}{c}\text { Cooking Time } \\
(\mathbf{m i n s})\end{array}$ & $\begin{array}{c}\text { Cooking loss } \\
(\mathbf{\%})\end{array}$ & $\begin{array}{c}\text { Water uptake } \\
\mathbf{( g )}\end{array}$ & $\begin{array}{c}\text { Cooking weight } \\
(\mathbf{\%})\end{array}$ \\
\hline $\mathrm{Y}_{0} \mathrm{~W}_{100}$ & $5.43 \pm 0.02^{\mathrm{a}}$ & $9.36 \pm 0.01^{\mathrm{b}}$ & $1.62 \pm 0.01^{\mathrm{c}}$ & $162 \pm 0.82^{\mathrm{c}}$ \\
\hline $\mathrm{Y}_{20} \mathrm{~W}_{80}$ & $6.36 \pm 0.01^{\mathrm{b}}$ & $9.31 \pm 0.01^{\mathrm{b}}$ & $1.93 \pm 0.02^{\mathrm{a}}$ & $193 \pm 1.63^{\mathrm{a}}$ \\
\hline $\mathrm{Y}_{30} \mathrm{~W}_{70}$ & $6.27 \pm 0.01^{\mathrm{b}}$ & $11.19 \pm 0.01^{\mathrm{a}}$ & $1.61 \pm 0.01^{\mathrm{c}}$ & $161 \pm 0.82^{\mathrm{c}}$ \\
\hline $\mathrm{Y}_{50} \mathrm{~W}_{50}$ & $6.92 \pm 0.10^{\mathrm{c}}$ & $13.06 \pm 0.25^{\mathrm{c}}$ & $1.71 \pm 0.01^{\mathrm{b}}$ & $171 \pm 1.25^{\mathrm{b}}$ \\
\hline $\mathrm{Y}_{70} \mathrm{~W}_{30}$ & $5.45 \pm 0.04^{\mathrm{a}}$ & $15.09 \pm 0.07^{\mathrm{d}}$ & $1.64 \pm 0.01^{\mathrm{c}}$ & $164 \pm 0.47^{\mathrm{c}}$ \\
\hline $\mathrm{Y}_{100} \mathrm{~W}_{0}$ & $7.06 \pm 0.08^{\mathrm{c}}$ & $12.46 \pm 0.03^{\mathrm{e}}$ & $2.04 \pm 0.01^{\mathrm{d}}$ & $204 \pm 0.94^{\mathrm{d}}$ \\
\hline
\end{tabular}

Significant difference is indicated by different letters within the same rom. $(p \leq 0.05)$

Table 6: Cooking properties of trifoliate yam-wheat noodle.

\begin{tabular}{|c|c|c|c|c|c|}
\hline $\begin{array}{c}\text { Noodles } \\
\text { Sample }\end{array}$ & Colour & Taste & Flavor & Texture & $\begin{array}{c}\text { Over all } \\
\text { acceptability }\end{array}$ \\
\hline $\mathrm{Y}_{0} \mathrm{~W}_{100}$ & $7.41 \pm 2.12^{\mathrm{b}}$ & $6.81 \pm 2.44^{\mathrm{a}}$ & $7.32 \pm 1.64^{\mathrm{a}}$ & $6.92 \pm 1.20^{\mathrm{b}}$ & $7.09 \pm 1.83^{\mathrm{a}}$ \\
\hline $\mathrm{Y}_{20} \mathrm{~W}_{80}$ & $4.61 \pm 0.00^{\mathrm{c}}$ & $5.01 \pm 1.70^{\mathrm{b}}$ & $5.11 \pm 1.37^{\mathrm{b}}$ & $6.21 \pm 2.30^{\mathrm{a}}$ & $6.26 \pm 2.05^{\mathrm{b}}$ \\
\hline $\mathrm{Y}_{30} \mathrm{~W}_{70}$ & $6.90 \pm 2.47^{\mathrm{a}}$ & $5.31 \pm 2.71^{\mathrm{c}}$ & $5.61 \pm 1.71^{\mathrm{c}}$ & $6.20 \pm 2.39^{\mathrm{a}}$ & $6.32 \pm 2.28^{\mathrm{b}}$ \\
\hline $\mathrm{Y}_{50} \mathrm{~W}_{50}$ & $5.30 \pm 1.89^{\mathrm{e}}$ & $4.90 \pm 2.23^{\mathrm{d}}$ & $5.90 \pm 2.08^{\mathrm{d}}$ & $4.90 \pm 2.23^{\mathrm{c}}$ & $5.92 \pm 1.44^{\mathrm{c}}$ \\
\hline $\mathrm{Y}_{70} \mathrm{~W}_{30}$ & $6.10 \pm 2.81^{\mathrm{f}}$ & $4.63 \pm 2.63^{\mathrm{e}}$ & $4.30 \pm 2.36^{\mathrm{e}}$ & $4.20 \pm 2.15^{\mathrm{c}}$ & $4.83 \pm 2.82^{\mathrm{d}}$ \\
\hline $\mathrm{Y}_{100} \mathrm{~W}_{0}$ & $4.49 \pm 1.16^{\mathrm{d}}$ & $4.10 \pm 2.25^{\mathrm{f}}$ & $4.80 \pm 1.55^{\mathrm{f}}$ & $4.11 \pm 1.73^{\mathrm{d}}$ & $5.52 \pm 2.75^{\mathrm{e}}$ \\
\hline Significant difference is indicated by different letters within the same rom. $(\mathrm{p} \leq 0.05)$ \\
\hline
\end{tabular}

Table 7: Sensory evaluation of trifoliate yam-wheat noodles.

both cases.

\section{Sensory properties of trifoliate yam-wheat noodles}

According to Alozie et al. [3] five on a scale of 9 is adjudged as acceptable. From Table 7 most panelists adjudged the optimally cooked noodles substituted with 20 - 50\% trifoliate yam flour to be as acceptable as the control noodles, although there were significant differences $(p<0.05)$ among some sensory attributes. Virtually all noodle samples were accepted, as no outright rejection was observed for any of the sensory parameters.

\section{Conclusion}

Noodles of comparable nutritional and sensory standards were produced from blends of trifoliate yam flour and wheat flour. Outcome of this study, if put into commercialization could reduce increase in the demand for importation of wheat for flour emanating from its exclusive utilization in bakery/pastry and also make it available for other useful purposes and thereby promoting food security. Anti-oxidant potential, microbial and shelf-life characteristics of these noodles are recommended for further studies.

\section{References}

1. Igyor MA, Ikyo SM, Gernah DI (2004) The food potential of yam (Dioscorea bulbifera). Niger Food J 22: 209-215.

2. IITA (2006) Yam: Research review. International Institute of Tropical Agriculture, Ibadan, Nigeria.

3. Alozie Y, Akpanabiatu MI, Eyong EU, Umoh IB, Alozie G, et al. (2009) Amino acid composition of Dioscorea dumetorum varieties. Pak J Nutri 8: 103-105.

4. Martin G, Treche S, Nuobi L, Agbor ET, Gwangwa S (1983) Introduction of flour from Dioscorea dumetorum in a rural area. Proceedings of the Second Triennial Symposium of the Society for Tropical Root Crops, African Branch, held in Douala Cameroon.

5. Eka OU (1998) Root and Tubers. In: Osagie AU, Eka OU (eds.) Nutritional quality of plant foods. Macmillian press, London, pp: 1-31

6. Afoakwa EO, Sefa-Dedeh S (2001) Chemical composition and quality changes occurring in Dioscorea dumetorum pax tubers after harvest. Food Chem 75 85-91.

7. Baiano A, Fares C, Peri G, Romaniello R, Taurino AM, et al. (2008) Use of toasted durum whole meal in the production of a traditional Italian pasta: chemical, mechanical, sensory and image analyses. Int J Food Sci Technol 43: $1610-1618$

8. Sissons M (2008) Role of durum wheat composition on the quality of pasta and bread: Invited Review Global Science Books. Food 2: 75-90.

9. Sanni LO, Bamgbose CA, Babajide JM, Sanni SA (2007) Production of instant cassava noodles. Proceedings of the $13^{\text {th }}$ ISTRC Symposium.

10. Chong LC (2007) Utilization of matured green banana (musa paradisiaca var. awak) flour and oat beta glucan as fibre ingredients in noodles.

11. Saifullah R, Abbas FMA, Yeoh SY, Azhar ME (2009) Utilization of green banana flour as a functional ingredient in yellow noodle. Int Food Res J 16: 373-379.

12. Ojure MA, Quadri JA (2012) Quality evaluation of noodles produced from unripe plantain flour using xanthan gum. IJRRAS 13: 740-752.

13. Abiodun OA, Akinoso R, Oladapo AS, Adepeju AB (2013) Influence of soaking method on the chemical and fuctional properties of trifoliate yam (Dioscorea dumetorum) flours. J Root Crop 39: 81-87.

14. Nagao S (1996) Processing technology of noodle products in Japan. In: Kruge JE, Matsuo RB, Dick JW (eds.) Pasta and Noodle Technology. American Association of Cereal Chemists, St. Paul, MN, pp. 169-194.

15. Udensi EA, Okaka JC (2000) Predicting the effect of blanching, drying temperature and particle size profile on the dispersibilty of cowpea flour. Niger Food J 18: 25-31.

16. AACC (1999) Approved methods of the AACC, method 56-30.01. American Association of Cereal Chemists, St.Paul, Minnesota, USA.

17. Kinsella JE, Melachouris N (1976) Functional properties of proteins in foods: A survey and Critical Revision. Food Sci Nutri 7: 219-280.

18. Iwuoha $\mathrm{Cl}$ (2004) Comparative evaluation of physicochemical qualities of flours from steam-processed yam tubers. J Food Chem 85: 541-551.

19. Tan LC (2003) Improving the application of gibberellic acid to prolong dormancy of yam tubers (Dioscorea spp.). J Sci Food Agri 83: 787-796.

20. FAO/WHO/UNU (1985) Energy and protein requirements. World Health Organisation Technology Report, Series no.724.

21. Yap CY, Chen Y (2001) Polyunsaturated fatty acid: Biological Significance biosynthesis and production by macroalgae and microalgae like organism. In Feng Chen, Yue Jiang (Eds) Algae and their biotechnological potential. Kluwer academic publisher pp: 1-32.

22. Chang HC, Wu LC (2008) Texture and quality properties of Chinese fresh egg noodle formulated with green seaweed (Monostroma nitidum). J Food Sci 73: 398-404.

23. Eko ND (2010) Quality evaluation of dried noodle with seaweeds purees substitution. Diponegoro University, Central Java, Indonesia.

24. Wang YQ, Zhang M, Mujumdar AS (2012) Influence of green banana flour substitution for cassava starch on the nutrition, color, texture and sensory quality in two types of snacks.

25. Senthil A, Ravi K, Bhat KK, Seethalakshmi MK (2002) Studies on the quality of fried snacks based on blends of wheat flour and saya flour. Food Qual Pref 13: $267-273$

26. Gabriel IO, Faith CU (2014) Production and evaluation of cold extruded and baked ready-to eat snacks from blends of breadfruit (Treculia africana),cashewnut (Anacardium occidentale) and coconut (Cocos nucifera) Food Sci Qual Manag 23: 2224-6088.

27. FAO (2010) Fats and fatty acids in human nutrition-Report of an expert consultation. FAO Food and Nutrition, Paper 91, Food and Agriculture Organization of the United Nations, Rome.

28. Hassan LG, Umar KJ (2004) Proximate and mineral composition of Seeds and pulp of Parkia biglobosa. Niger J Basic Appl Sci 13: 15-27.

29. Wirjatmadi B, Merryana A, Purwanti S (2002) Marketing strategy noodle dried seaweed (Euchema cottonii) and iodine rich fiber system with marketing mix. J Penelitian Media Eksata 3: 89-104.

30. Riley CK, Wheatley AO, Asemota HN (2006) Isolation and characterization of starches from eight Dioscorea alata cultivars grown in Jamaica. Afri J Biotechnol 5: 1528-1538.

31. IFIS (2005) Dictionary of food science and technology, International Food Information Service. Blackwell Publishing, Oxford, UK. 
Citation: Akinoso R, Olatoye KK, Ogunyele OO (2016) Potentials of Trifoliate Yam (Dioscorea dumetorum) in Noodles Production. J Food Process Technol 7: 609. doi:10.4172/2157-7110.1000609

Page 6 of 6

32. Ellis WO, Oduro I, Barimah J, Otoo JA (2003) Quality of starch from six Japanese sweet potato varieties in Ghana. Afri J Root Tuber Crop 5: 38-41.

33. Oduro I, Ellis WO, Nyarko L, Koomson G, Otoo JA, et al. (2001) Physicochemical and pasting properties of flour from four sweetpotato varieties in Ghana. Proceedings of the Eighth Triennial Symposium of the International Society for Tropical Root Crops (ISTRC-AB), Ibadan, Nigeria.

34. Baker RC, Wonghan P, Robbins KR (1994) Fundamentals of new food products developments. Science, Elsevier Science, Amsterdam.

35. Siddaraju NS, Ahmed F, Urooj A (2008) Effect of incorporation of Dioscorea alata flour on the quality and sensory attributes of indian dehydrated products. World J Dairy Food Sci 3: 34-38.

36. Kulkarni KD, Noel G, Kulkarni DN (1996) Sorghum malt-based weaning food formulations: preparation, functional properties and nutritive value. Food Nutri Bul 13: 322-327

37. Soni RL, Sharma SS, Dun D, Gharia MM, Ahmeda J (1993) Physico chemica properties of Quercus leucotrocophora (oak). Starch/Starke 45: 127-130.

38. Mohamed A, Xu J, Singh M (2010) Yeast leavened banana-bread: Formulation, processing, colour and texture analysis. Food Chem 118: 620-626.

39. Mares DJ, Campbell AW (2001) Mapping components of flour and noodle color in Australian wheat. Aust J Agri Res 52: 1297-1309.

40. Rayas-Duarte P, Mock CM, Satterlee LD (1996) Quality of spaghetti containing buckwheat, amaranth, and lupin flours. Cereal Chem 73: 381-387.

41. Ovando-Martinez M, Sáyago-Ayerdi S, Agama-Acevedo E, Goñi I, BelloPérez LA, et al. (2009) Unripe banana flour as an ingredient to increase the indigestible carbohydrates of pasta. Food Chem 113: 121-126. 